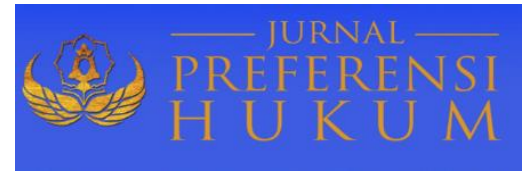

\title{
PERTANGGUNGJAWABAN PIDANA PELAKU TINDAK PIDANA KORUPSI DANA HIBAH PENGADAAN BIBIT SAPI (STUDI PUTUSAN NOMOR 1/PID.SUS-TPK/2019/PN DPS)
}

\author{
I Kadek Edy Sanjaya, I Nyoman Gede Sugiartha, Ida Ayu Putu Widiati \\ Fakultas Hukum Universitas Warmadewa, Denpasar - Bali, Indonesia \\ kadekedysanjaya06@gmail.com
}

\begin{abstract}
Abstrak
Penelitian ini bertujuan untuk menganalisa pertanggungjawaban pidana pelaku tindak pidana korupsi dana hibah pengadaan bibit sapi. Isu hukum yang muncul dari penelitian ini meliputi: Bagaimana pengaturan hibah dan hubungannya dengan tindak pidana korupsi, serta pertanggungjawaban pidana terhadap pelaku tindak pidana korupsi pengadaan bibit sapi (Putusan Nomor 1/PPid.Sus-TPK/2019/PN Dps). Metode yang digunakan dalam penelitian ini adalah penelitian hukum normatif dengan pendekataan perundang- undangan, konseptual dan kasus. Berdasarkan hasil penelitian ini, dapat disimpulkan beberapa hal: 1) Pengaturan hibah diatur dalam Pasal 1666, 1682 dan 1682 KUH Perdata; 2) Hubungan hibah dengan tindak pidana korupsi terkait dengan hibah merupakan ladang basah yang dimanfaatkan oknum untuk melakukan korupsi. 3) Berdasarkan Putusan Nomor 1/Pid.Sus- TPK/2019/PN Dps, terdakwa terbukti melanggar Pasal 3 jo Pasal 18 Undang-undang Nomor 31 Tahun 1999 tentang Pemberantasan Tindak Pidana Korupsi jo Undang-undang Nomor 20 Tahun 2002. Bentuk pertanggungjawaban pidana pelaku tindak pidana korupsi berupa pidana penjara selama 2 (dua) tahun dan 4 (empat) bulan dikurangi masa tahanan sementara dan berdasarkan perintah agar terdakwa tetap ditahan dan pidana denda sebesar Rp 50.000.000,- (lima puluh juta rupiah) subsidair 2 (dua) bulan kurungan, serta dibebankan untuk membayar uang pengganti sebesar Rp 127.350.000,- (seratus dua puluh tujuh juta tiga ratus lima puluh ribu rupiah). Adapun saran yang dapat diberikan kepada pembaca yaitu melalui pendidikan dan sikap keteladanan dari pada pemimpin yang menjadi tombak utama sebagai cerminan dari pemerintah terhadap generasi penerus. Bagi peneliti selanjutnya yang akan meneliti mengenai tindak pidana korupsi agar dapat menggali lebih mendalam lagi tentang bagaimana pemerintah berperan dalam upaya pencegahan tindak pidana korupsi.
\end{abstract}

Kata Kunci: Pertanggungjawaban Pidana; Pelaku; Korupsi; Hibah

\begin{abstract}
This study aims to analyze the "Criminal Accountability of Corruption Actors in Grants for Beef Procurement Grants". Legal issues arising from this study include: How is the arrangement of grants and their relationship with criminal acts of corruption, as well as criminal liability for perpetrators of corruption in the procurement of cattle (Decision Number 1/PPid. Sus-TPK/2019/PN Dps). The research method used in this research is normative legal research with statutory, conceptual and case approaches. Based on the results of this study, it can be concluded several things: 1) Grant arrangements are regulated in Article 1666, 1682 and 1682 of the Civil Code; 2) The relationship between grants and corruption related to grants is a wet field that is used by individuals to commit corruption. 3) Based on Decision Number 1 / Pid.Sus-TPK / 2019 / PN Dps, the defendant is proven to have violated Article 3 in conjunction with Article 18 of Law Number 31 of 1999 concerning Eradication of Corruption Crimes in conjunction with Law Number 20 of 2002. Form of criminal liability the perpetrators of corruption in the form of imprisonment for 2 (two) years and 4 (four) months minus the temporary detention period and based on orders so that the defendant remains in custody and a fine of Rp 50,000,000 (fifty million rupiah) subsidair 2 (two) a month of confinement, and is charged to pay a replacement money of Rp 127,350,000 (one hundred twenty seven million three hundred fifty thousand rupiah). The advice that can be given to the reader is through education and exemplary attitude from the leader who becomes the main spear as a reflection of the government towards the next generation. For further researchers who will examine the crime of corruption in order to dig deeper about how the government plays a role in efforts to prevent corruption.
\end{abstract}

Keywords: Criminal Responsibility; Perpetrator; Corruption; Grant 


\section{PENDAHULUAN}

Perkembangan pembangunan dan peningkatan pertumbuhan perekonomian yang menjadikan kehidupan masyarakat menjadi makmur dan sejahtera di pengaruhi oleh Anggaran Pendapatan Belanja Daerah (APBD) dan Anggaran Pendapatan Belanja Negara (APBN). Kemakmuran dan kesejahteraan masyarakat Indonesia masih belum tercapai secara maksimal. Indikator atau tolak ukur untuk dapat mengetahui belum tercapainya kesejahteraan dan kemakmuran rakyat beberapa diantaranya adalah tingkat kemiskinan, kesenjangan sosial berkaitan dengan pendapatan, pengangguran dan lain sebagainya. Penyebab belum tercapainya kesejahteraan dan kemakmuran rakyat tersebut dikarenakan masih banyaknya terjadi masalah-masalah yang sangat meresahkan masyarakat, masalah yang paling fenomenal adalah korupsi. Hal ini didukung oleh hasil penelitian dari Wiryawan \& Tjatrayasa (2016) yang menyatakan bahwa penyebab terjadinya korupsi yang banyak terjadi di Indonesia karena seseorang beranggapan bahwa jika kekayaan didapat maka orang tersebut dapat dikatakan sukses. Maka dari itu orang akan melakukan cara apapun untuk mendapatkan kekayaan tersebut termasuk dengan cara korupsi yang merugikan masyarakat banyak dan negara. Lemahnya pendidikan agama, moral, dan etika juga merupakan penyebab lain yang mengakibatkan orang melakukan korupsi. Selain itu, faktor ekonomi (Hariyani, Priyarsono, \& Asmara, 2018); (Toruan, 2014), demi kemakmuran sendiri (Argiya, 2013), dan aspek perundangan yang memberikan peluang bagi para actor pembuat kebijakan untuk melanggengkan korupsi (Riawati, 2016) menjadi pemicu dari tindak pidana korupsi. Oleh karena itu, pentingnya peranan pendidikan anti korupsi dalam menciptakan masyarakat Madani di Indonesia (Komara, 2019)..

Ketentuan mengenai korupsi termuat dalam Undang-Undang Nomor 31 Tahun 1999 jo Undang-Undang Nomor 20 Tahun 2002 tentang perubahan atas Undang-Undang Nomor 31 Tahun 1999 tentang Pemberantasan Tindak Pidana Korupsi atau disingkat UU PTPK, artinya bahwa korupsi diatur secara khusus dalam UU PTPK diluar Kitab Undang-Undang Hukum Pidana atau KUHP. Tindak pidana korupsi sering diistilahkan sebagai white collar crime atau kejahatan kerah putih yang dalam perkembangannya semakin pesat dirasakan, hal ini disebabkan karena gaya hidup dan kebutuhan yang semakin meningkat. Korupsi tersebut secara meluas dan sistematis tidak saja merugikan perekonomian negara, namun juga mengganggu stabilitas sosial dan ekonomi masyarakat, maka mesti dilakukan penganggulangan secara luar biasa (Effendy, 2010).

Salah satu peluang untuk terjadinya korupsi adalah dalam hal pengadaan barang/jasa pemerintah. Bidang ini sangat berpengaruh terhadap proses membangun kekuatan perekonomian negara, namun juga sangat rentan terjadinya penyelewengan terkait administrasi yang tidak sesuai yang berindikasi terjadinya tindak pidana korupsi yang akan menyebabkan merosotnya perekonomian negara. Permasalahan korupsi di Indonesia masih saja terjadi meskipun telah banyak aturan hukum yang mengatur untuk pemberantasan tindak pidana korupsi. Hal yang memprihatinkan terlebih pelaku-pelaku yang seharusnya mempertanggungjawabkan perbuatannya tersebut susah untuk dihadapkan di muka hukum.

Sebelum menyatakan dapat atau tidaknya pelaku korupsi dalam pengadaan barang/jasa dimintai pertanggungjawaban maka sudah barang tentu dikaji terlebih dahulu perbuatannya tersebut termasuk kedalam benturan kepentingan dalam jabatan atau merupakan kesalahan dalam jabatan. Pertanggungjawaban dalam jabatan dibebankan kepada negara atau pemerintah berdasarkan aturan hukum atas kesalahan dari perbuatan dalam jabatan tersebut, sedangkan pertanggungjawaban pribadi menurut hukumnya dibebankan kepada seseorang atas perbuatan berdasarkan asas kesalahan dalam perbuatannya secara perseorangan atau pribadi.

Penelitian terkait tindak pidana korupsi telah dikaji sebelumnya oleh beberapa peneliti seperti Syamsudin (2007) dengan judul penelitiannya "Korupsi dalam Perspektif Budaya Hukum"; Anfasa (2014) "Pertanggungjawaban Pidana Pelaku Tindak Pidana Korupsi Kedelai Bersubsidi (Studi Putusan Pengadilan Negeri Tanjung Karang No.26/Pid.TPK/2012/PN.TK)"; Nugroho (2016) "Pertanggungjawaban Tindak Pidana Korupsi di Indonesia Berdasar Ajaran Monistis dan Dualistis Dalam Perspektif Hakim"; Setiadi (2018) dalam penelitiannya berjudul "Korupsi Di Indonesia Penyebab, Hambatan, Solusi dan Regulasi" dan Alhakim \& Soponyono (2019) "Kebijakan Pertanggungjawaban Pidana Korporasi Terhadap Pemberantasan Tindak Pidana Korupsi". Mengacu pada latar belakang dan penelitian sebelumnya di atas, penelitian ini dilakukan untuk mengkaji pengaturan dana hibah dan hubungannya dengan tindak pidana korupsi, serta pertanggungjawaban pidana terhadap pelaku tindak pidana korupsi pengadaan bibit sapi. 


\section{METODE}

Metode yang digunakan dalam penelitian ini adalah hukum normative dengan pendekatan pendekataan perundang-undangan, konseptual dan kasus. Data dari penelitian ini adalah data primer dan data sekunder. Data primer diperoleh dari melalui studi lapangan dan data sekunder diperoleh dari studi pustaka. Penelitian ini dianalisis secara kualitatif.

\section{HASIL DAN PEMBAHASAN \\ Pengaturan Hukum Dana Hibah}

Istilah hibah sudah tidak asing lagi dalam kehidupan bermasyarakat, hibah sendiri merupakan suatu pemberian secara cuma-cuma namun tidak terus menerus. Hibah adalah suatu pemberian oleh seseorang berupa suatu benda yang diberikan secara cuma-cuma kepada si penerima hibah guna suatu keperluannya.

Pendapat Kansil mengenai hibah merupakan suatu perjanjian antara dua pihak, dimana pihak pertama menyerahkan suatu barang kepada pihak kedua sebagai penerimanya (Kansil, 2002). R. Subekti mengartikan hibah sebagai pemberian, dimana si pemberi hibah menyanggupi secara cuma-cuma secara mutlak memberikan suatu barang kepada penerima hibah. Sebagai suatu perjanjian (obligor) hibah tersebut secara langsung dan salah satu pihak tidak dapat menarik kembali begitu saja secara sepihak (Subekti, 1995).

Hibah sejauh ini telah diatur Pada dasarnya hibah merupakan suatu pemberian suatu benda oleh seseorang kepada orang lain guna suatu keperluan. Pasal 1666 - Pasal 1693 KUHPerdata mengatur mengenai hibah. Meskipun hibah dikatakan sebagai suatu perjanjian yang sifatnya sepihak yang dirumuskan dalam pasal $1666 \mathrm{KUH}$ Perdata tidaklah dapat ditarik kembali, namun apabila telah mendapat persetujuan dari penerima hibah maka hibah dapat ditarik kembali. Apabila dikemudian hari terhadap hibah tersebut terjadi suatu penarikan ataupun penghapusan, maka apapun bentuk hibah tersebut harus dikembalikan tanpa adanya beban-beban yang melekat pada hibah tersebut. Hibah merupakan suatu pemberian dari seseorang kepada orang lain guna suatu kepentingan diberikan secara cuma-cuma. Hibah dalam pasal 1667 KUH Perdata merumuskan penghibahan hanya dapat dilakukan apabila benda hibah telah ada, namun jika benda tersebut baru akan ada maka penghibahan tidak dapat dilakukan atau dinyataka batal (Subekti \& Tjitrosudibio, 1979).

Korupsi dapat diartikan sebagai macam perbuatan yang buruk sebagai suatu kebusukan, kehajatan, ketidakjujuran, tidak bermoral, kata-kata atau ucapan yang menghina atau memfitnah (Hamzah, 1991). Tindak pidana korupsi dapat mengganggu berbagai aspek kehidupan bermasyarakat baik dari aspek sosial, ekonomi serta menghambat tata pergaulan masyarakat yang baik. Unsur-unsur tindak pidana korupsi dirumuskan dalam Pasal 2 dan Pasal 3 ayat (1) UU PTPK. Pasal 2 merumuskan unsur-unsur:
a. Setiap orang;
b. Menguntungkan diri sendiri, orang lain atau korporasi;
c. Dengan cara melawan hukum;
d. Yang dapat merugikan keuangan negara atau perekonomian negara.

Pasal 3 ayat (1) juga merumuskan:

a. Setiap orang;

b. Dengan tujuan memperkaya diri sendiri, orang lain atau korporasi;

c. Menyalahgunakan kewenangan, kesempatan atau sarana yang ada padanya karena jabatan atau kedudukan;

d. Dapat merugikan keuangan negara atau perekonomian negara.

Korupsi dalam lingkup Dana Hibah memang menjadi perbincangan hangat di lingkungan masyarakat. Permasalahan ini terjadi dikarenakan lemahnya pengawasan terhadap pengajuan, pencairan, atau realisasi dana hibah tersebut yang menjadikan suatu proyek pengadaan melalui pemberian dana hibah dijadikan sebagai ladang basah bagi para oknum yang tidak bertanggungjawab untuk melakukan korupsi. 


\section{Hubungan Hibah dengan Tindak Pidana Korupsi}

Adapun permasalahan lain yang dapat terjadi adalah salah sasaran dalam pelaksanaan program, dimana program yang awalnya disusun dan dianggarkan untuk dibiayai dialihkan dengan program lain yang dapat diprioritaskan. Penyimpangan yang terjadi dalam proyek pengadaan barang dan/atau jasa pemerintah khususnya yang bersumber dari APBN sesuai ketentuan Pasal 2 Peraturan Presiden Republik Indonesia Nomor 16 Tahun 2018 tentang Pengadaan Barang/jasa Pemerintah yang diberikan dana hibah dapat ditemui berawal dari penggelembungan dana permohonan, data tender yang fiktif, serta kecurangan yang dapat dilakukan dengan mengalirkan dana ke kantong pribadi. Bahkan untuk dapat mencairkan dana anggaran tersebut tidak jarang mengalir jauh kepada instansi pemerintah yang menaungi bidang Anggaran dan Keuangan Kas Negara (Sutedi, 2012). Berkaitan dengan kasus suatu tindak pidana korupsi di bidang hibah dapat ditunjukan atau dibuktikan dengan adanya indikasi terjadinya perbuatan pemalsuan dokumen, penentuan harga dengan nilai tinggi secara sendiri, penggelembungan dana anggaran dan pelaporan yang tidak sesuai dengan permohonan.

Kasus tindak pidana korupsi dana hibah pengadaan bibit sapi yang terjadi di Desa Carangsari, Kecamatan Petang, Kabupaten Badung dalam Putusan Nomor 1/Pid.Sud-TPK/2019/PN Dps bahwa berdasarkan atas keterangan saksi-saksi dan ahli dikaitkan dengan barang bukti dan surat bukti yang ada dan terdakwa, maka diperoleh fakta-fakta hukum dalam persidangan yang didapat dari buktibukti serta keterangan saksi-saksi dan ahli, terlihat adanya data fiktif berkaitan dengan anggota kelompok yang menyatakan dirinya tidak mengetahui sebagai anggota kelompok dan tidak pernah menandatangani Berita Acara Rapat, kemudian berdasarkan hasil evaluasi lapangan tidak adanya kesesuaian jumlah antara yang ada di lapangan dengan yang dilaporkan, ini artinya bahwa terjadi pemalsuan dokumen serta penentuan harga dengan nilai tinggi secara sendiri.

Secara sederhana hibah dijadikan sebagai kesempatan bagi oknum- oknum tidak bertanggungjawab melakukan korupsi dengan menghandalkan kedudukannya yang dapat merugikan keuangan dan perekonomian negara, maka sudah jelas bahwa tindak pidana korupsi dapat terjadi dalam bidang hibah dengan bertolak pada kasus tersebut diatas. Artinya bahwa dalam pelaksanaan dan pengelolaan hibah apabila kurangnya pengawasan di dalamnya, maka akan menimbulkan terjadinya tindak pidana korupsi, kemudian akan menyebabkan kerugian terhadap keuangan atau perekonomian Negara.

\section{Pertanggungjawaban Pidana bagi Pelaku Tindak Pidana Korupsi dalam Pengadaan Bibit Sapi}

Pengertian pertanggungjawaban pidana tidaklah termasuk kedalam pengertian tindak pidana itu sendiri. Pengertian tindak pidana hanyalah memberikan rujukan bahwa seseorang dilarang melakukan suatu perbuatan pidana dan dapat diancam dengan sanksi pidana (Ali, 2011). Roeslan Saleh mengartikan pertanggungjawaban pidana merupakan suatu peristiwa diteruskannya celaan secara objektif terdapat dalam suatu tindak pidana dan secara subjektif ada dan telah terpenuhinya syarat untuk dapat dipidana. Pada prinsipnya landasan dari suatu tindak pidana adalah asas legalitas, sedangkan landasan mengenai dapat atau tidaknya seseorang dipidana adalah asas kesalahan. Pelaku dapat jatuhi sanksi pidana apabila ia telah memenuhi unsur kesalahan terhadap tindakan pidana yang ia lakukan tersebut (R.M, 2002).

Permasalahan pertanggungjawaban pidana dewasa ini mengalami perubahan yang cukup drastis dengan ditetapkannya korporasi sebagai subjek yang dapat dimintai pertanggungjawaban pidana dalam hukum positif yang berlaku di Indonesia (Butarbutar, 2015). Penyelewengan dalam kegiatan pengadaan barang/jasa dari pemerintah yang berujung pada terjadinya korupsi, perlu adanya kejian terhadap bentuk tindakan si pelaku dalam kedudukannya sebagai anggota instansi pemerintah atau berkedudukan sebagai orang pribadi. Pengkajian ini bertujuan untuk mengimplikasikan pertanggungjawaban yang akan diminta kepada si pelaku. Potensi terjadinya tindak pidana korupsi dalam pengadaan barang/jasa dilakukan oleh rekanan bahkan pengelola kegiatan pengadaan barang/jasa. Resiko terjadinya tindak pidana korupsi biasanya dilakukan bersama-sama dalam kegiatan pengadaan barang/jasa.

Kasus tindak pidana korupsi dalam kegiatan pengadaan barang/jasa salah satunya adalah korupsi pengadaan bibit sapi yang terjadi di Desa Carangsari, Kecamatan Petang, Kabupaten Badung yang dilakukan oleh Ketua Kelompok Sapi "Sari Amerta" berdasarkan Putusan Nomor 1/Pid.SudTPK/2019/PN Dps. Pelaku melakukan tindak pidana korupsi dengan memalsukan Rancangan Anggaran Biaya (RAB) proyek pengadaan bibit sapi, sehingga terjadi penggelembungan dana dalam Laporan Pertanggungjawaban yang tidak ada kesesuaian seperti apa yang ada di lapangan. 
Berdasarkan uraian di atas bentuk pertanggungjawaban pidana pelaku tindak pidana dana hibah pengadaan bibit sapi adalah pertanggungjawaban pribadi. Hakim dalam mempertimbangkan suatu perkara sudah barang tentu harus memperhatikan aspek yuridis terkait unsur-unsur yang terkandung dalam pasal yang didakwakan berdasarkan fakta-fakta yang terungkap dalam persidangan dan juga alat bukti yang sah. Berdasarkan pada Pasal 44 KUHP hakim haruslah menyatakan unsur-unsur yang termuat dalam pasal yang didakwakan merupakan klausula yang sah dan meyakinkan serta tanpa adanya alasan pemaaf atau pembenar.

Sejalan dengan apa yang diuraikan diatas perlu juga dicantumkan hal-hal yang meringankan dan hal-hal yang memberatkan yang dikuatkan oleh aspek yuridis yang meliputi aspek akibat, pribadi dan psikologis si pelaku, kemasyarakatan. Majelis Hakim harus mempertimbangkan aspek-aspek tersebut dalam menjatuhkan putusan guna putusan tersebut dapat dipertanggungjawabkan kepada masyarakat berdasarkan atas hak asasi si pelaku atau rasa keadilan masyarakat dari segi hukum serta harus memenuhi ketentuan hukum yang berlaku yang menjadikan putusan tersebut sah secara hukum. Berdasarkan kasus tersebut diatas maka dapat dianalisis sebagai berikut:

Terdakwa didakwa telah melakukan tindak pidana korupsi dalam proyek pengadaan bibit sapi, sebagaimana ditemukan adanya penyimpangan antara jumlah dana yang diterima dengan dana yang digunakan, hibah tidak digunakan sesuai dengan proposal pengajuannya, pelaporan pertanggungjawaban penggunaan dana dibuat oleh terdakwa seolah-olah dana tersebut habis.

Terdakwa telah terbukti secara sah dan meyakinkan melakukan tindak pidana korupsi atas dasar pertimbangan hakim bahwa perbuatan Terdakwa telah memenuhi unsur-unsur sebagaimana diatur dalam Pasal 3 jo. Pasal 18 Undang- Undang Nomor 31 Tahun 1999 jo Undang-Undang Nomor 20 Tahun 2001 tentang Perubahan atas Undang-Undaang Nomor 31 Tahun 1999 tentang Pemberantasan Tindak Pidana Korupsi serta berdasarkan atas fakta-fakta hukum yang dijelaskan dan diterangkan dalam persidangan.

Mengingat berdasarkan Pasal 3 jo. Pasal 18 Undang-Undang Nomor 31Tahun 1999 jo UndangUndang Nomor 20 Tahun 2001 tentang Perubahan atas Undang-Undaang Nomor 31 Tahun 1999 tentang Pemberantasan Tindak Pidana Korupsi, Undang-Undang Nomor 8 Tahun 1981 tentang Kitab Undang-Undang Hukum Acara Pidana (KUHAP), serta peraturan-peraturan lain yang berkaitan, maka berdasarkan Pasal 3 jo. Pasal 18 Undang-Undang Nomor 31 Tahun 1999 jo. Undang-Undang Nomor 20 Tahun 2001 tentang Perubahan atas Undang-Undang Nomor 31 Tahun 1999 tentang Pemberantasan Tindak Pidana Korupsi, Terdakwa I Made Suweca diancam dipidana penjara selama 2 (dua) tahun dan 4 (empat) bulan dikurangi masa tahanan sementara dan berdasarkan perintah agar Terdakwa tetap ditahan dan pidana denda sebesar Rp. 50.000.000,- (lima puluh juta rupiah) Subsidair 2 (dua) bulan kurungan, serta dibebankan untuk membayar uang pengganti sebesar Rp. 127.350.000,- (seratus dua puluh tujuh juta tiga ratus lima puluh ribu rupiah) dengan ketentuan jika Terdakwa tidak membayar uang pengganti paling lama dalam waktu 1 (satu) bulan sesudah putusan pengadilan memperoleh kekuatan hukum tetap, maka harta bendanya dapat disita oleh Jaksa dan dilelang untuk menutupi uang pengganti tersebut, dalam hal Terdakwa tidak mempunyai harta benda yang mencukupi untuk membayar uang pengganti, maka diganti dengan pidana penjara selama 8 (delapan).

\section{SIMPULAN}

Berdasarkan hasil yang telah dijelaskan di atas, maka dapat disimpulkan bahwa pengaturan dana hibah diatur dalam Pasal 1666, Pasal 1682 dan Pasal 1683 KUH Perdata, dimana pada prinsipnya hibah atau penghibahan akan mengikat pada si penghibah atau akan menimbulkan sesuatu sebelum diterimanya penghibahan tersebut. Hubungan antara hibah dan tindak pidana korupsi berada dalam ruang lingkup dimana hibah merupakan ladang basah bagi oknum tidak bertanggungjawab untuk melakukan korupsi. Artinya bahwa dalam pelaksanaan dan pengelolaan hibah apabila kurangnya pengawasan didalamnya, maka akan menimbulkan terjadinya tindak pidana korupsi. Pertanggungjawaban pidana terhadap pelaku tindak pidana korupsi adalah dapat diancam dengan pidana penjara seumur hidup atau paling singkat 1 tahun dan paling lama 20 tahun dan/ atau denda paling sedikit Rp. 50.000.000,- (lima puluh juta rupiah) dan paling banyak Rp. 1.000.000.000,- (satu milyar rupiah). Kasus tersebut diatas, pelaku dipidana penjara selama 2 tahun 4 bulan yang kemudian dikurangi selama masa tahanan dan dipidana denda sebesar Rp 50.000.000,- (lima puluh juta rupiah) Subsidair 2 bulan kurungan, serta dibebankan untuk membayar uang pengganti sebesar Rp. 
127.350.000,- (seratus dua puluh tujuh juta tiga ratus lima puluh ribu rupiah). Hukuman yang dijatuhi kepada terdakwa sudah berdasarkan atas bukti-bukti yang didapatkan selama proses persidangan, dimana terjadi penyimpangan jumlah dana yang dimohonkan dengan yang digunakan serta yang dilaporkan, adanya data fiktif yang seolah-olah dana hibah tersebut habis, serta penggunaan dana hibah tersebut tidak sesuai dengan permohonan yang diajukan. Adapun saran yang dapat diberikan kepada pembaca yaitu melalui pendidikan dan sikap keteladanan dari pada pemimpin yang menjadi tombak utama sebagai cerminan dari pemerintah terhadap generasi penerus. Bagi peneliti selanjutnya yang akan meneliti mengenai tindak pidana korupsi agar dapat menggali lebih mendalam lagi tentang bagaimana pemerintah berperan dalam upaya pencegahan tindak pidana korupsi.

\section{DAFTAR PUSTAKA}

Alhakim, A., \& Soponyono, E. (2019). Kebijakan Pertanggungjawaban Pidana Korporasi Terhadap Pemberantasan Tindak Pidana Korupsi. Jurnal Pembangunan Hukum Indonesia, 1(3), 322-336. doi:https://doi.org/10.14710/jphi.v1i3.322-336

Ali, M. (2011). Dasar-Dasar Hukum Pidana. Jakarta: Sinar Grafika.

Anfasa, F. (2014). Pertanggungjawaban Pidana Pelaku Tindak Pidana Korupsi Kedelai Bersubsidi (StudiPutusanPengadilanNegeriTanjungKarang No.26/Pid.TPK/2012/PN.TK). POENALE: Jurnal Bagian Hukum Pidana, 2(4). Retrieved from https://jurnal.fh.unila.ac.id/index.php/pidana/article/view/217

Argiya, V. S. P. M. (2013). Mengupas Tuntas Budaya Korupsi yang Mengakar serta Pembasmian Mafia Koruptor Menuju Indonesia Bersih. RECIDIVE, 2(2). Retrieved from https://jurnal.uns.ac.id/recidive/article/view/32330

Butarbutar, R. (2015). Pertanggungjawaban Korporasi Dalam Tindak Pidana Korupsi Pengadaan Barang/Jasa Pemerintah Dibidang Kontruksi. Bekasi: Gramata Publishing.

Effendy, M. (2010). Pemberantasan Korupsi dan Good Governance. Jakarta: Timpani Publish.

Hamzah, A. (1991). Korupsi di Indonesia. Jakarta: Sinar Grafika.

Hariyani, H. F., Priyarsono, D. S., \& Asmara, A. (2018). Analisis Faktor-Faktor yang Memengaruhi Korupsi di Kawasan Asia Pasifik. Jurnal Ekonomi Dan Kebijakan Pembangunan, 5(2), 32-44. doi:10.29244/jekp.5.2.32-44

Kansil, C. S. T. (2002). Pengantar Ilmu Hukum Dan Tata Hukum Indonesia. Jakarta: Balai Pustaka.

Komara, E. (2019). Peranan Pendidikan Anti Korupsi dalam Menciptakan Masyarakat Madani di Indonesia. Insan Cita: Journal of Islamic Studies in Indonesia and Southeast Asia, 4(1), 77-88. Retrieved from http://journals.mindamas.com/index.php/insancita/article/view/1200

Nugroho, D. M. (2016). Pertanggungjawaban Tindak Pidana Korupsi di Indonesia Berdasar Ajaran Monistis dan Dualistis Dalam Perspektif Hakim. QISTIE: Jurnal Ilmu Hukum, 9(1). doi:http://dx.doi.org/10.31942/jqi.v9i1.1748

R.M, S. (2002). Hukum Pidana Materil: Unsur-Unsur Objektif Sebagai Dasar Dakwaan (Edisi Kedu). Jakarta: Sinar Grafika.

Riawati, N. (2016). Potensi Korupsi dalam Kebijakan Publik Studi Kasus Korupsi Program Penanganan Sosial Ekonomi Masyarakat di Provinsi Jawa Timur. Jurnal Ilmu Sosial Dan Ilmu Politik, 19(2), 154. doi:10.22146/jsp.10851

Setiadi, W. (2018). Korupsi Di Indonesia Penyebab, Hambatan, Solusi dan Regulasi. Jurnal Legislasi Indonesia, 15(3), 249-262. Retrieved from http://ejurnal.peraturan.go.id/index.php/jli/article/view/234

Subekti, R. (1995). Aneka Perjanjian. Bandung: Citra Aditya Bakti.

Subekti, R., \& Tjitrosudibio, R. (1979). Kitab Undang-Undang Hukum Perdata. Jakarta: Pradnta Paramita.

Sutedi, A. (2012). Aspek-aspek Hukum Pengadaan Barang dan Jasa Dan Berbagai Permasalahannya. Jakarta: Sinar Grafika.

Syamsudin, M. (2007). Korupsi dalam Perspektif Budaya Hukum. Unisia, 30(64), 183-194. doi:10.20885/unisia.vol30.iss64.art7

Toruan, H. D. L. (2014). Pertanggungjawaban Pidana Korupsi Korporasi. Jurnal Rechts Vinding: Media Pembinaan Hukum Nasional, 3(3), 397-416. Retrieved from https://rechtsvinding.bphn.go.id/ejournal/index.php/jrv/article/view/33

Wiryawan, P. A., \& Tjatrayasa, M. (2016). Analisis Hukum Penyebab Terjadinya Tindak Pidana Korupsi dan Pertanggungjawaban Pidananya. Kertha Wicara: Journal Ilmu Hukum, 5(2). 
Retrieved from https://ojs.unud.ac.id/index.php/kerthawicara/article/view/19138 